\title{
METHODS OF HUMIDITY DETERMINATION Part I: Hygrometry
}

\author{
Katrin Rübner ${ }^{1}$, D. Balköse $e^{2}$ and E. Robens ${ }^{3 *}$ \\ ${ }^{1}$ BAM Federal Institute for Materials Research and Testing, Unter den Eichen 87, 12205 Berlin, Germany \\ ${ }^{2}$ İzmir Institute of Technology Faculty of Engineering Department of Chemical Engineering, Gulbah çeköyü Urla İzmir, Turkey \\ ${ }^{3}$ Institut für Anorganische Chemie und Analytische Chemie der Johannes Gutenberg-Universität, Duesbergweg 10-14 \\ 55099 Mainz, Germany
}

Part I of the short survey covers definitions of air humidity and the respective measuring methods such as hygrometry, psychrometry, dew point measurement, LIDAR hygrometry and humidity sensors. Techniques based on property changes of matter with adsorbed moisture from air are reviewed.

Keywords: humidity, hygrometry, psychrometry, water, weather forecast

\section{Introduction}

Although in highly developed countries, we are mostly in protected environments, weather is still governing our life and it influences also industrial processes. Weather forecasting has been made over a long time and beginning in the Middle Ages a large variety of instruments has been developed [1-4]. Water vapour in air causes atmospheric phenomena such as rain, snow or frost and affects solids by corrosion of metals, caking of powders, and deterioration of delicate technical devices. Humidity sensors with linear, quick and reversible responses were developed for measuring water vapour concentration in air [5]. This article aims at reviewing properties of water, definitions such as relative and absolute humidity and measurement techniques of air humidity.

\section{Water structures}

Under environmental conditions water exists in all three classical states of matter: solid, liquid and gas. The water molecule is non-linear (Fig. 1) and therefore polar. In comparison with other liquids it has anomalous features; about 63 exceptional properties are recorded [6].

In gaseous phase water is present as a dimeric complex, along with mono-atoms (Fig. 2). Air contains always water vapour in a concentration from near zero up to the saturation value determined by temperature. In addition, liquid or solid agglomerates may be present, visible as clouds, droplets, snow or

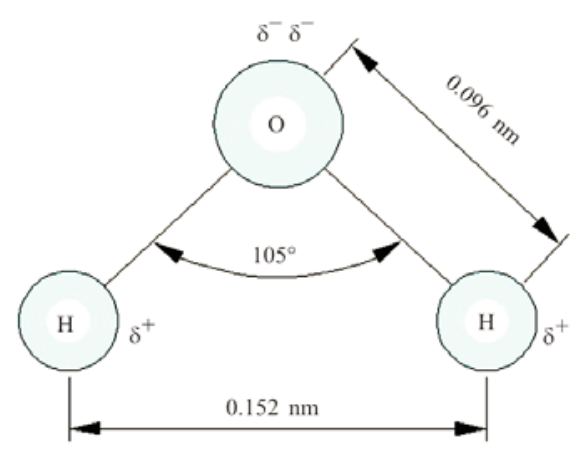

Fig. 1 Structure of water molecule

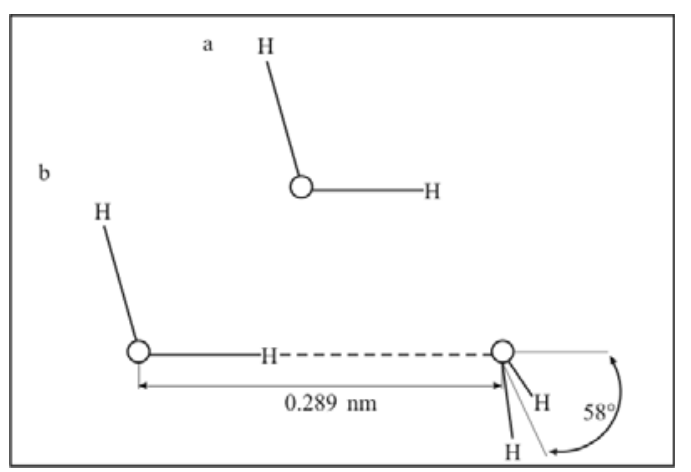

Fig. 2 Structure of monomeric and dimeric water molecules in vapour

hailstones. Contaminations should be taken into account, so little droplets of ionic solutions are formed with salt from sea water, and dust provides nuclei for condensation. 


\section{Humidity}

The following concerns the water content of the air and of process gases. Air humidity is the amount of water vapour in the air, disregarding the possible presence of liquid or solid aggregates like raindrops, fog, snow or hailstones. The parameter, air humidity, is governed only by the availability of water and the thermal energy available for evaporation, which is a function of temperature. Air humidity can be expressed in several ways [7]:

- Absolute humidity $A H_{\text {air }}$ is defined as the amount of water vapour $m_{\mathrm{w}}$ present in unit mass $m_{\text {air }}$ or unit volume $V_{\text {air }}$ of dry air.

$$
A H_{\text {air }}=\frac{m_{\mathrm{w}}}{m_{\text {air }}}\left[\mathrm{g} \mathrm{kg}^{-1}\right]
$$

or

$$
A H_{\text {air }}=\frac{m_{\mathrm{w}}}{m_{\text {air }}}\left[\mathrm{g} \mathrm{m}^{-3}\right]
$$

- Relative humidity $R H_{\text {air }}$ is the ratio of the amount of water vapour in the air $m_{\mathrm{w}}$ at a specific temperature to the maximum amount that the air could hold at that temperature $m_{\mathrm{w}, \max }$, usually expressed as a percentage.

$$
R H_{\text {air }}=\frac{m_{\mathrm{w}}}{m_{\mathrm{w}, \max }} \cdot 100[\%]
$$

Another definition is the ratio of the partial pressure of water vapour $p$ in a gaseous mixture of air to the saturation vapour pressure $p_{0}$ at that temperature. The values differ slightly near the saturation point:

$$
R H_{\text {air }}=\frac{p}{p_{0}} \cdot 100[\%]
$$

Relative humidity is the most frequently encountered measurement of humidity because it is regularly used in weather forecasts.

- Specific humidity $S H_{\text {air }}$ is the ratio of water vapour to air (dry air plus water vapour) in a particular volume of air. Specific humidity ratio is expressed as a ratio of $\mathrm{kg}$ of water vapour, $m_{\mathrm{w}}$, per $\mathrm{kg}$ of air, $m_{\mathrm{air}}+m_{\mathrm{w}}$

$$
S H_{\text {air }}=\frac{m_{\mathrm{w}}}{m_{\text {air }}+m_{\mathrm{w}}}
$$

- Associated with the relative humidity is the dew point. That is the temperature at which water vapour saturates from gas into liquid or solid usually forming rain, snow, frost or dew. At this temperature the relative humidity is $100 \%$. From the dew point temperature the relative humidity can be derived by means of tables.

\section{Air humidity measuring methods}

The peculiar characteristic of the water molecule facilitates its identification and allows the application of very different methods to determine humidity. The methods are standardised in all industrial states [8]. Water vapour is a primary contaminant in process gases at very low-levels of particular interest to the semiconductor industry. Therefore efforts are directed toward developing water vapour measurements and standards at the part per billion level and below for characterization of moisture concentration measuring instruments and standards normally used in industrial applications for contamination control in process gases. In Germany standards are compiled in a vademecum [9]. Calibration of instruments is made e.g. in the USA by PhysikalischTechnische Bundesanstalt - Deutscher Kalibrierdienst, in the UK by National Physical Laboratory United Kingdom Accreditation Service [10].

\section{Hygrometry}

The earliest hygrometers made in the $15^{\text {th }}$ century were balances loaded on one side with textile $[11,12]$. Today the gravimetric method is applied as a primary standard for humidity measurements. The NIST gravimetric hygrometer has an uncertainty of $0.1 \%$ mass fraction. Furthermore, a suitable mass sensor is the quartz crystal balance the surface of which is covered by a hygroscopic film or by a microporous substance $[13,14]$. Ultrathin Linde Type A (LTAtype) molecular sieves grown on a quartz crystal microbalance have high sensitivity, good reversibility and long life at low humidity ranges [15].

The simplest and still widely used mechanical hygrometer is the hair hygrometer of Horace Bénédict de Saussure [16] (Fig. 3). It measures the elongation of hair with increasing humidity due to swelling of the hair cells. Hairs from humans, sheep or horses are used; today also plastic strips or fibres are used. Whereas the mass adsorbed is somewhat proportional to relative air humidity the elongation of the hair or fibre (up to $\sim 2.5 \%$ ) is not linear and the scale is spread in the middle of the measuring range.

More accurate measurements and electronic recording of results are achieved with a coulometric hygrometer. It measures the change in the electrical impedance or resistance of a thin layer of a hygroscopic material, e.g. lithium chloride or phosphorus pentoxide (Fig. 4). Other hygrometers sense changes in electric capacity, volume, or the transparency of various substances that respond to relative humidity.

The measurement of the electrical resistance of hygroscopic thin films or of semiconductors can be used in hygrometry and likewise as sensors in head 


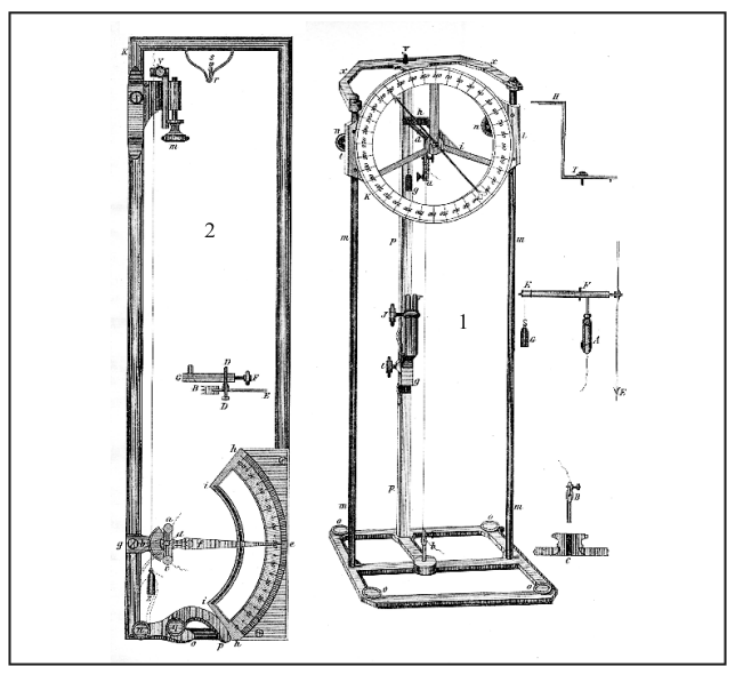

Fig. 3 Hair hygrometer of Horace Bénédict de Saussure (1783). 1 - large hygrometer. The hair is stretched between a and b. 2 - hand hygrometer. The hair is stretched between y and z. (Drawing from [16])

space analysis in order to determine material humidity. Typical substances include lithium chloride, stearic acid and zinc stearate [17]. The relation of conductivity to relative humidity in general is not linear and may be applied only within a restricted measuring range. High sensitivity humidity sensors based on single $\mathrm{SnO}_{2}$ nanowires have linear response in conductivity to humid air [18]. Cells with manganese oxide-clay solid electrolytes have good linearity and fast response in galvanic potential to changes in humidity [19].

Optical methods include the observation of colour transition of chemical compounds when reacting with water molecules. Such indicators are widely

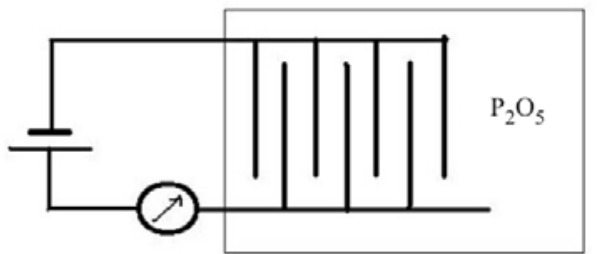

Fig 4 Coulometric hygrometer: Keidel cell (1950): platinum electrodes on a substrate covered with a thin film of $\mathrm{P}_{2} \mathrm{O}_{5}$

used to control the activity of drying agents and as breakthrough indicators [20]. Test methods of qualitative water indication include redden of blue cobalt(II)chloride [18, 21]. Usually blue cobalt-II-chloride is dispersed in silica gel. Sensors consist of such salts dispersed on different substrates such as cellulose, cellulose acetate, polyvinyl pyrollidon, wool, calcium sulphate, silica gel, zeolites and alumina. Wool impregnated with cobaltous chloride is blue in dry form and converts to yellow on moisture adsorption [22]. Humidity indicating gels, light blue in dry form and dark blue in moist form, were obtained by dispersing copper sulphate in silica gel. Yellow lead iodide is obtained from potassium lead iodide upon moisture adsorption. Such indicators are widely used to control the activity of drying agents like silica gel and as breakthrough indicators [23]. Polymer-dye systems changing colour with air humidity can also be used as humidity sensors. A high sensitivity optical humidity probe was developed by using Nafion-crystal violet films. Reversible change in absorbance of the films at $650 \mathrm{~nm}$ with relative humidity was linear in the zero to $1 \%$ range [24].

Table 1 Usual methods for the measurement of air and gas humidity

\begin{tabular}{|c|c|}
\hline Method & Principle of measurement \\
\hline & Measuring methods \\
\hline Hygrometer & $\begin{array}{l}\text { Measurement of parameters, like change of length, mass, electric resistance, electric } \\
\text { capacity, sorption, dew point, that depends on humidity. }\end{array}$ \\
\hline Psychrometer & Measurement of evaporation coldness by temperature difference. \\
\hline \multirow[t]{2}{*}{ Dew point meter } & Observation of condensation at a surface in dependence of temperature. \\
\hline & Humidity sensors \\
\hline Dielectric measurement & $\begin{array}{l}\text { Capacitive measurement with a condenser taking the advantage of the high dielectric } \\
\text { constant of water. }\end{array}$ \\
\hline Electric conductivity measurements & Electrochemical measurement of conductivity. \\
\hline Microwave and infrared spectroscopy & Measurement of absorption of radiation. \\
\hline $\begin{array}{l}\text { Nuclear magnetic resonance } \\
\text { spectroscopy }\end{array}$ & $\begin{array}{l}\text { Measurement of resonance between a high-frequency electromagnetic field and }{ }^{1} \mathrm{H} \\
\text { nucleus of water of a sample, which is arranged into a strong homogeneous magnetic } \\
\text { field. }\end{array}$ \\
\hline Activation analysis & Measurement of absorption of fast neutrons or $\gamma$-rays. \\
\hline Moisture indicator & Qualitative test observing colour change. \\
\hline
\end{tabular}




\section{Psychrometry}

In 1825 August constructed the first psychrometer (Fig. 5) on a proposal of Leslie [25, 26]. Richard Assmann added a ventilator, and this aspiration psychrometer [27] is regarded as a standard instrument for air humidity measurements. It consists of two thermometers, the bulb of one of it is kept wet usually by means of a humidified cotton envelope. Evaporation from the wet bulb lowers the temperature, so that the wet-bulb thermometer shows a lower temperature $T_{\text {wet }}$ than that of the dry-bulb thermometer $T_{\text {dry }}$. Evaporation is supported by an air stream generated either by a ventilator or by whirling the thermometer in the air by hand. From the temperature difference, the partial pressure of water vapour in the air $p_{\mathrm{H}_{2} \mathrm{O}}$ can be determined using Sprung's formula [28]:

$$
p_{\mathrm{H}_{2} \mathrm{O}}=p_{0}-\left(T_{\text {dry }}-T_{\text {wet }}\right)
$$

where $p_{0}$ stands for the saturation pressure at the temperature of the wet bulb $T_{\text {wet }}$ and $C$ is a constant $C=0.67 \mathrm{hPa} \mathrm{K}^{-1}$ for height up to $500 \mathrm{~m}$ and $T_{\text {wet }}>0^{\circ} \mathrm{C}$. By means of graphical tables the relative humidity can be derived.

\section{Dew point hygrometry}

In 1820, John Frederic Daniell invented a dew-point hygrometer, which came into widespread use. The Lambrecht dew-point hygrometer is a polished metal mirror that is cooled by evaporation of ether until moisture just begins to condense onto it, observed optically then (Fig. 6) and today by means of a photosensor. The temperature at the beginning of opaqueness of the metal is the dew point temperature. Knowing the atmospheric temperature and the dew-point temperature, the relative humidity can be determined by means of a table.

\section{LIDAR hygrometry}

LIDAR (light detection and ranging) is an optical remote sensing technology that measures properties of scattered light to find information of a distant target $[29,30]$. By means of laser pulses and measuring the time delay between transmission of a pulse and detection of the reflected signal the distance to an object can be determined. Whereas radar uses radio waves, LIDAR uses much shorter wavelengths of the electromagnetic spectrum, typically in the ultraviolet, visible, or near infrared region. In general it is possible to image a feature or object only about the same size as the wavelength, or larger. Thus LIDAR is highly sensitive to aerosols and cloud particles. An object needs to produce a dielectric discontinuity in order to reflect the transmitted wave. Different types of scattering are used for different

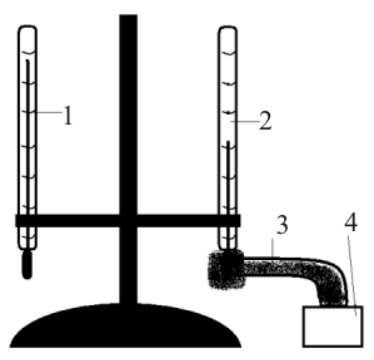

Fig. 5 August psychrometer (1825). 1 - dry thermometer, 2 - wet thermometer, 3 - cotton strip, 4 - water reservoir

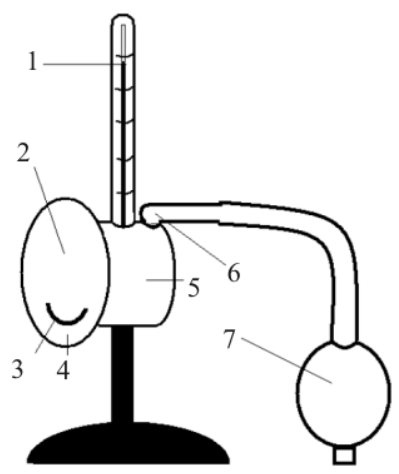

Fig. 6 Lambrecht dew point hygrometer (1881).1 - thermometer, 2 - metal mirror, 3 - gap, 4 - reference mirror, 5 - container filled with ether, 6 - air supply, 7 - air pump

LIDAR applications, most common are Rayleigh scattering, Mie scattering and Raman scattering as well as fluorescence. The wavelengths are ideal for measurements of smoke and other airborne particles (aerosols), clouds, and air molecules. Since the deployment of the GPS (Global Positioning System) in the 1980s, precision positioning has become possible. Airborne LIDAR systems monitor glaciers and have the ability to detect subtle amounts or growth or decline. In atmospheric physics, LIDAR is used as a remote detection instrument to measure densities and movement of certain constituents of the middle and upper atmosphere, such as clouds. With Raman spectroscopy inelastic scattering is observed. Since the energy change in this case is quantified the spectrum is characteristic for the target molecule. Water molecules scatter predominantly green light: Nd:YAG laser light with a wavelength of $532 \mathrm{~nm}$ is reflected with $660 \mathrm{~nm}$ wavelength. This process is applied to determine the relation of a water vapour mixture in the atmosphere.

\section{Conclusions}

For the determination of atmospheric humidity the methods developed in the $18^{\text {th }}$ and $19^{\text {th }}$ centuries still 
are predominant. Psychrometry is regarded as a standard method. Increasingly, the measurement is converted to an electrical signal allowing for transmission of results and control of processes. Efforts are directed toward developing water vapour measurements and standards at the part per billion level and below.

\section{References}

1 E. Robens, K. Rübner, P. Staszczuk and A. Dabrowski, Ann. Pol. Chem. Soc., 2 (2003) 670.

2 E. Robens and K. Rübner, GIT Z. Labortechnik, 47 (2003) 1046.

3 E. Robens, K. Rübner, P. Staszczuk and A. Dąbrowski, ICTAC News, 38 (2005) 39.

4 R. Wernecke, Industrielle Feuchtemessung, Wiley - VCH, Weinheim 2003.

5 J. Fraden, Ed., Humidity and Moisture Sensors. Handbook of Modern Sensors, Springer, New York 2004.

6 M. Chaplin, Water Structure and Behavior, 2007, http://WWW.lsbu.ac.uk/water/index.html.

7 S. Gal, Die Methodik der Wasserdampf-Sorptionsmessungen, Springer, Berlin 1967.

8 K. Rübner, E. Robens and D. Balköse, J. Therm. Anal. Cal., DOI: 10.1007/s10973-008-9370-y.

9 DIN/VDI, Umweltmeteorologie. Meteorologische Messungen, Teil 1: Wind, Temperatur, Feuchte und Niederschlag. DIN-VDI-Taschenbuch 332, Beuth, Berlin 1999.

10 NIST, Thermodynamic quantities - Humidity measurements - http://ts.nist.gov/MeasurementServices/ Calibrations/Humidity.cfm, 2007, NIST - National Institute of Standards and Technology.

11 E. Robens and A. Dąbrowski, J. Therm. Anal. Cal., 86 (2006) 17.

12 S. Kiefer and E. Robens, J. Therm. Anal. Cal., 94 (2008) 613.

13 V. M. Mecea, J. O. Carlsson and R. V. Bucur, Sens. Actuators A, 53 (1996) 371.

14 T. Brokate, T. Gast, E. Robens and Z. Ali, J. Therm. Anal. Cal., 71 (2003) 25.
15 S. Mintova, S. Mo and T. Bein, Chem. Mater., 13 (2001) 901.

16 H. B. de Saussure, Versuch über die Hygrometrie. Ostwald's Klassiker der exakten Wissenschaften, A. J. von Oettingen, Ed., Vol. 115+119, Engelmann Neuchâtel/Leipzig 1783/1900.

17 S. Ozturk, D. Balköse, S. Okur and J. Umemura, Colloids Surf. A: Physicochem. Eng. Aspects, 302 (2007) 67.

18 D. Balköse, S. Ulutan, F. C. Özkan, S. Celebi and S. Ülkü, Appl. Surf. Sci., 134 (1998) 39.

19 K. Miyazaki, M. Hieda and T. Kano, Ind. Eng. Chem. Res., 36 (1999) 88.

20 D. Berkün D. Balköse, F. Tıhmınlığlu and

S. Alsoy Atlinkaya, J. Therm. Anal. Cal., DOI: 10.1007/s10973-008-9354-y.

21 D. Balköse, U. Köktürk and H. Yilmaz, Appl. Surf. Sci., 147 (1999) 77.

22 D. Balköse and S. Ülkü, Water vapour adsorption and desorption on cobaltous chloride impregnated wool in packed column, in Polymers and Composites: Synthesis, Properties and Applications, R. A. Pethrick, G. E. Zaikov and D. Horak, Eds, Nova Science Publishers, New York 2007, pp. 35-40.

23 Q. Kuang, C. Lao, Z. L. Wang, Z. Xie and L. Zheng, J. Am. Chem. Soc., 129 (2007) 6070.

24 H. Dacres and H. Narayanaswamy, Talanta, 69 (2006) 631.

25 J. J. Berzelius, Chemische Operationen und Geräthschaften, $3^{\text {rd }}$ Ed., Lehrbuch der Chemie, Vol. 10, Arnoldsche Buchhandlung, Dresden, Leipzig 1841.

26 R. Tomaschek, Mechanik/Wärmelehre/Akustik, $12^{\text {th }} \mathrm{Ed}$., Grimsehls Lehrbuch der Physik, Vol. 1, Teubner, Leipzig, Berlin 1942.

27 M. Wiehle, Magdeburger Persönlichkeiten, 1993.

28 A. Sprung, Z. Angew. Meteorol., Das Wetter, 5 (1888) 105.

29 A. P. Cracknell and L. Hayes, Introduction to Remote Sensing, $2^{\text {nd }}$ Ed., Taylor and Francis, London 2007.

30 Wikipedia, Lidar, http://en.wikipedia.org/wiki/LIDAR, 2007, Wikipedia.

DOI: $10.1007 / \mathrm{s} 10973-008-9349-8$ 